\title{
Fine Lines: cosmetic advertising and the perception of ageing female beauty
}

\author{
By Caroline SEARING* $\mathcal{E}$ Hannah Zeilig*
}

\begin{abstract}
Fine Lines is a study investigating the language used in adverts for female facial cosmetics (excluding makeup) in UK Vogue magazine. The study queries whether this has been affected by the introduction and rise in popularity of minimally invasive aesthetic procedures to alleviate the signs of facial ageing. The contemporary cultural landscape is explored: this includes the ubiquitous nature of advertising as well as the growth of the skincare market. Emergent thematic analysis of selected advertisements showed a change in the language used before the introduction of the aesthetic procedures (1992 and 1993) compared with later years (2006 and 2007). We have noted a decline in numbers of advertisements within some themes (nourishing in particular showed a marked fall in number of mentions) while others have shown increases (those offering protection against UV radiation and pollution increased by $50 \%$ in the later data set). The remaining thematic categories were relatively constant over the period of study, though the emphasis shifted within the themes over time. This article concludes by asserting that the language has changed, that the vocabulary has become more inventive and that skincare products appear to be marketed as complementary to cosmetic procedures. In addition,

* Caroline Searing and Hannah Zeilig, London College of Fashion, Fashion Business School, University of the Arts London
\end{abstract}


International Journal of Ageing and Later Life

some of the products appear to be being marketed as luxury items, something to be bought because owning and using it gives you pleasure and bestows prestige on the owner.

Keywords: advertising, cosmetics, language, ageing, consumerism, Botox.

\section{Background to the Study}

In common with most developed countries, Britain is in the process of undergoing a demographic transition (Canning 2011), which means that there are now more people aged 60 and over in the United Kingdom than there are under 18 (Office for National Statistics 2013a). Over the past 50 years (1960-2010), the average life span has increased by about 10 years for men and 8 years for women (Office for National Statistics 2012). On average, life expectancy at birth increased across all local areas of England and Wales with men now expected to live to 79.1 years and women to an average of 82.9 years (Office for National Statistics 2013b).

It is inevitable that the ageing of populations has also become an opportunity for the emergence of new markets; older people are an exciting potential source of custom for those selling housing, holidays, pension products and, of course, skincare products. Indeed, it was in the 1980s and 1990s that several researchers, including Featherstone and Hepworth (1991), began to consider the relationship between ageing and consumerism in western societies. These commentators suggest that those in midlife feel compelled to maintain their bodies in a perpetually youthful state because western cultures valorise youth. More recently, there have been criticisms of this predominantly social constructionist approach to the ageing body (Biggs 1997) with an emphasis on theories that place more emphasis on the inner psychic self (Schwaiger 2006). Nevertheless, the media continue to reinforce the negative aspects of ageing and the dire consequences it will have for our health and our looks.

On a biological level, intrinsic physical ageing is inevitable - but increasingly, there is a sense that this does not have to be accepted. There is a bewildering array of injectables, fillers and other procedures not to mention alluring skin creams that claim to help us "fight" ageing. The face, and in particular facial skin, has always been a focus for the beauty 
industry because the skin is obviously subject to the ageing process more than any other component of the face (Ribeiro 2011). Over the course of the $20^{\text {th }}$ century, innovations in skincare and cosmetics have been imaginative and include the use of hormones in the 1930s, the introduction of hypoallergenic cosmetics in the 1950s followed more recently by "organic" makeup and that which incorporates sunscreen (Ribeiro 2011).

Unsurprisingly then, the facial skincare market is big business. Globally, it was valued by Euromonitor at US\$80.5 bn in 2012, and it is expected to expand further in the coming years. Almost two-thirds of the sales were from facial moisturisers and anti-ageing products (Matthews 2013). The number of anti-ageing skincare launches increased by 30\% in 2012 (Mintel cited in Matthews 2013). It is anticipated that future growth in skincare will come from anti-ageing products with the rise in the number of older people being one of the major market drivers. The growth in this market is fuelled by advertising.

Estimates of the number of advertisements seen in a day range from the hundreds to the thousands (Abu-Saud 2013). They are ubiquitous and there is an ever-increasing range of media being used to communicate these messages. From newspapers and periodicals to radios and television and more recently computers, tablets and smart phones, today's consumers live in a visual information culture (Schroeder 2002). Some underground and train stations and most airports in Western capital cities even have television screens that are used exclusively for advertising. Brands, including those concerned with marketing cosmetics, use the global market culture to promote their products through carefully constructed images that project not only their products but also the brand and corporate images (Schroeder 2002). This diverse range of media formats means that the companies are able to present their messages in a wide variety of ways to their chosen consumers. As noted by Johnson (2008):

Advertising has gained cultural prominence because it is the engine of consumer culture. (Chapter 1: p. 1)

Moreover, advertising is a purveyor of ideological codes that gain their meaning both through verbal and visual messages that are then interpreted by the spectator (Johnson 2008). She also notes that language must be seen as integral to the images created by advertising. She states that 
International Journal of Ageing and Later Life

"language has the capacity to frame, either sharply, or more diffusely, an idea or disposition" (p. 4). Little information is provided about the products themselves; rather, the message is read and interpreted through the reader's own cultural discourse. It is interesting to note the reduction in the amount of text between the 1930s and the period of study in the 2000s: complicated explanations are no longer required to get the message across, but the combination of an image and text together creates the meaning. This resonates with the constructionist approach of Hall (2013) and acknowledges the public, social character of language and the shifting nature of meaning that is constructed rather than inherent. The written text (as distinct from illustrations or graphics) of the advertisements that formed part of this study operates in a similarly sophisticated symbolic way whereby words are consciously used to conjure an array of meanings that are not necessarily related to the objects they describe. Cosmetic advertisements have only a tenuous relationship to the material world; rather, they construct a self-referential system using words in connection with imagery that represents a concept or concepts. Often, those are related to luxury, with images of gold or jewellery, or youth and beauty and the use of models barely into their twenties.

The London College of Fashion holds a near-complete print archive of Vogue, a British fashion magazine which has been published since 1916. This collection provided the inspiration and data source for this investigation.

\section{Literature Review}

\section{Cosmetic Skincare Advertising}

The history of cosmetic and skincare advertising is at least a century old (of course, its use is much older than that), and cosmetic adverts have been a feature of women's magazines, including Vogue since their beginnings (Jones 2010). The start of the $20^{\text {th }}$ century heralded the emergence of L'Oréal, Elizabeth Arden and Helena Rubinstein and thus the birth of the beauty industry and advertising that is familiar today. After the First World War, cosmetics became cheaper and were widely advertised. Since that time, there has been a steady increase in cosmetic advertising. A brief look at Vogue from 1930 shows that both Elizabeth Arden and Helena Rubinstein 
are already established advertisers. Elizabeth Arden was among the first in the $20^{\text {th }}$ century to imply that the user could look younger through the use of cosmetics. One example is their 1936 advertisement that cleverly inverts the famous $19^{\text {th }}$ century poem by Browning promising "Farewell to Age! Grow young along with me, the best is yet to be!" (Elizabeth Arden 1936, cited in Dade 2007). In 1950, Helena Rubinstein used scientific evidence in one of their cosmetic advertisements. In language and tone, this is evocative of $21^{\text {st }}$ century advertising as it promised to correct sagging contours with the regular use of the Contour Lift Film. The language, visual imagery and claims of the advertisements of the 1960s emphasised cosmetic use for younger women and for decoration, though there were still some advertisements aimed at older women wishing to look younger. The emphasis in the 1970s was on what is "natural" both in terms of look and in ingredients (Dade 2007).

The last decades of the $20^{\text {th }}$ century saw advertisements increasingly targeted at the baby boomer generation, a large but also an ageing market. Clearly then, cosmetic advertisements both reflect and are indicative of their cultural eras.

\section{Anti-Ageing Products}

As science comes to a greater understanding of the ageing process, more and more sophisticated "anti-ageing" products and treatments have been developed. This pace of development picked up with the introduction of Retin-A and AHA-based products into the cosmetic market in the early 1990s (Ellison 2014), and it quickened with the licensing, by the United States Food and Drug Administration, in 2002 of botulinum toxin A (Botox ${ }^{\mathrm{TM}}$, Allergan, United States) for the reduction of facial wrinkles, followed in 2005 by Restylane ${ }^{\mathrm{TM}}$ (Medicis Aesthetics Inc., United States), the first of the injectable fillers containing hyaluronic acid which are used to replace facial volume that has been lost due to age. The latest weapons in the fight have been the introduction of bio-identical and human growth hormones, promising, according to Weintraub (2010) cited in Ellison 2014), not only a more youthful appearance but also a longer and healthier life.

Aesthetic plastic surgery also has a long history. Mendelson (2013) quotes a reference to a procedure carried out in about $600 \mathrm{BCE}$, and for much of its history, it has been about correcting deformity, but more 
International Journal of Ageing and Later Life

recently it has come to be about rejuvenation as people seek to retain a youthful look. The first aesthetic procedures focused on reducing the wrinkles and sagging associated with advancing age. Modern procedures offer more sophisticated solutions and may involve bone enhancement, autologous fat injections or fat removal (Asken 1990; Helfrich et al. 2008; Wan et al. 2009). The annual audit data published in February 2014 by the British Association of Aesthetic and Plastic Surgeons (BAAPS), with the glorious title "Britain Sucks" indicate that over 50,000 cosmetic procedures were conducted in Britain in 2013, with women accounting for $90.5 \%$ of all of the procedures carried out (BAAPS 2014). Anti-ageing procedures were popular with eyelid surgery up by $14 \%$, face and neck lifts up by $13 \%$, fat transfer by $15 \%$ and brow lifts by $17 \%$.

Non-surgical procedures have also shown a big rise in popularity (Franks 2014) and were estimated to account for more than nine in ten cosmetic procedures and almost three-quarters of the $3.6 \mathrm{bn}$ market value of the cosmetic treatments market in 2010 (Department of Health 2013). Bayer (2005) notes that in 2003, four of the top five non-surgical cosmetic procedures were specifically targeted at the visible signs of ageing, namely Botox $^{\mathrm{TM}}$ injections, microdermabrasion, chemical peels and collagen injections. Their quick administration, quick recovery time and moderate pricing make them a very attractive proposition and a viable alternative to the more expensive, and more invasive, cosmetic surgery options. Their greater effectiveness when measured against skin creams is likely to be another factor in their popularity (Franks 2014). Of these minimally invasive procedures, Botox ${ }^{\mathrm{TM}}$ is the most popular of all. Although there are no exact figures as to the number of treatments in Britain in any given year, figures are available for the United States where a total of 283,107 Botox ${ }^{\mathrm{TM}}$ injections were given in 2013, a rise of nearly 38,000 over 2012 with by far the greatest number being given to female patients and $84 \%$ of those procedures requested by women under the age of 35 (American Association of Facial Plastic and Reconstructive Surgery 2014). Cosmetic surgery is no longer the preserve of the rich and famous, and where once it was something to be denied, it has become an acceptable, even normal, thing to have done to enhance appearance (Brooks 2004; Dingman et al. 2012). It is also increasingly popular as a means of attempting to meet societal standards of beauty. 


\section{Women, Appearance and Ageing}

As indicated by Montemurro and Gillen (2013), the sexually desirable woman is young and thin. They go on to suggest that a critical element of body image for heterosexual women is the desire to create something which appeals to men. Authors appear divided as to whether the availability of cosmetic surgery and non-surgical procedures is having the effect of pushing women to conform to ideals of youth and beauty or whether the opposite is true in that achievement of these ideals is, in fact, empowering to women (Brooks 2004). These dichotomous views are cogently discussed by Ribeiro (2011) who, in a detailed historical discussion, stresses that women have never solely seen themselves as "victims" of "male-fabricated judgements of appearance" because they themselves are centrally involved in establishing ideals of beauty: "women choose their clothes and their makeup, not with men in mind, but themselves" (p. 329).

Hurd Clarke and Griffin (2007) examined older women's perceptions of ageing and found that the women tended to define natural ageing as that accompanied by a lack of cosmetic treatments. Many, of their respondents, however, admitted to having undergone cosmetic treatments in an effort to ward off the visible signs of ageing. Cosmetic treatments in this context included anti-wrinkle creams, cosmetics, hair dyes, cosmetic surgery and non-surgical treatments such as Botox ${ }^{\mathrm{TM}}$, chemical peels, injectable fillers and microdermabrasion. The key incentive for undergoing these treatments seemed to be a desire to boost self-esteem (Mitskavets 2013), with $53 \%$ of those adults questioned citing this as their main reason. The other two key incentives were looking more attractive to others $(29 \%)$ and looking younger $(27 \%)$.

A whole anti-ageing cosmetic industry has thus grown up to help fight the war against ageing. Hurd Clarke and Griffin (2007) found that some of the women in their study on "natural" and "unnatural" ageing felt that an aged appearance should be fought against using whatever beauty procedures and interventions were required and were available. The notion that time is a flaw on the faces of women has a long cultural history and yet disturbingly retains contemporary resonance. Being Otherwise, a contemporary artwork by Parnell (Woodspring \& Parnell 2015), reminds us of the universal cultural patterns that underlie our contemporary image saturated society. Despite ground breaking early analyses of old age by feminists 
International Journal of Ageing and Later Life

such as Sontag (1978) and de Beauvoir (1972), research into the subjective experiences of older women began belatedly in the field of social gerontology only gaining momentum in the late 1990s (Furman 1997).

However, the importance of acknowledging the different social pressures and expectations for women as they enter later life is now widely acknowledged. As outlined by the Commission on Older Women (2015), the current generation of active older women in their fifties and sixties has led very different lives from their mothers. Some have more disposable income than at earlier life stages and are part of a cohort that is more fashion and appearance conscious than their predecessors. The rise of consumer culture coincides with the ageing of the current baby boomers that are familiar with beauty parlours, shopping malls and new fitness practices (Gilleard \& Higgs 2013). However, there remain structural inequalities in society that have resulted in old age poverty for many women, who are caring for ageing parents or partners whilst still working (Hogan \& Warren 2012).

The notion that older women become socially "invisible" as their roles within the family and workplace are eroded is often discussed (Furman 1997; Segal 2014). Ideas connected with the invisibility of older women are also linked with the emphasis on the appearance and sexuality of women, which alters as women age and are less subject to the male gaze. Yet, the notion that women are less visible in old age may no longer be wholly applicable to the "new" generation of older women who are redefining the ageing terrain just as they established youth culture (Woodspring 2016). The putative invisibility of older women is being challenged both within popular culture and through academic work. Mair et al. (2015) similarly found that the women in their study were more concerned with looking good than with looking young. Moreover, as noted by Lewis et al. (2011), early retirement is a phenomenon strongly associated with baby boomers women as well as men - and means that this cohort will remain active for a long time, which possibly foreshadows a growing demand for cosmetics and clothing that "fits" with retirement lifestyles. In addition, the potential of the "grey pound" as older women are staying active and healthy for longer is gradually being appreciated as a vast marketing opportunity (Lewis et al. 2011).

Notwithstanding this apparent focus on "new" ways of ageing for women, older women still tend to be airbrushed out of society's 
meta-narratives (Hogan \& Warren 2012). Similarly, there are very few images of older women that are truly diverse or that present alternatives. Above all, Hurd Clarke (2011) makes the point that:

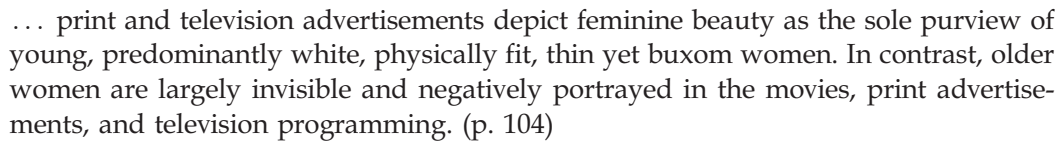
young, predominantly white, physically fit, thin yet buxom women. In contrast, older women are largely invisible and negatively portrayed in the movies, print advertisements, and television programming. (p. 104)

The emphasis remains unerringly upon the ways in which women can resist age, retain their looks and remain middle-aged. This is perpetuated by television and in the media where there is an uncritical focus on the antiageing industry and a tendency to focus on white heterosexual women.

\section{Language and Imagery in Cosmetic Advertising}

Several studies have been conducted into the imagery and language used in the advertising of cosmetic products (Dade 2007; Dalton \& Berrett 1994; Ellison 2014; Reschke 1998; Smirnova 2012). Some have concentrated on figurative language (Monalisa \& Dahlan 2013), and others have been more concerned with comparing visual and verbal content between countries (Wang 2008). Kuang and Guo (2010) performed a critical discourse analysis of English cosmetic advertisements, while Prochásková (2008) focused on syntactic analysis. She found that the most frequent use of language was in the form of simple sentences using the imperative since they have the strongest selling power. Campos (1987) considered the semantics of femininity in cosmetic advertising, while Kilyeni (2012) looked at the promise of instant beauty in the language of print advertisements for cosmetics.

We could find no study which considered whether the increase in popularity and use of surgical and non-surgical aesthetic treatments has had an effect on the way in which facial cosmetics are advertised. Thus, this study has been designed to look at changes in the language used in cosmetic advertisements before and after the rise in popularity of minimally invasive cosmetic treatments, a perspective not covered by the other papers in the field. Dalton and Berrett (1994) examined the evolution of the language of advertising for women between 1890 and 1990. They noted that, throughout this period, there has been an evolution of both the format 
International Journal of Ageing and Later Life

and the language used in cosmetic advertising, but their study focused on the idea of "ideal beauty" towards which all women should aspire.

This study has also been informed by perspectives from critical gerontology and feminism, which emphasise the fundamental importance of the social context in understanding human ageing. As Utz comments in her 2011 essay, the women of the baby boom generation are questioning whether they really have to age in the same ways as their mothers and grandmothers. As one respondent from her study remarked "I am not going to be old yet."

\section{Aims and Methods of the Study}

The research question at the heart of this study is whether cosmetic advertising in Vogue magazine has been affected by the rise in the availability and popularity of non-surgical, minimally invasive cosmetic procedures such as Botox ${ }^{\mathrm{TM}}$ (licensed in 2002) and Restylane ${ }^{\mathrm{TM}}$ (licensed in 2005).

The aim of this small-scale study was to examine linguistic changes in advertisements in Vogue magazine between those published 10 years before the introduction of these innovations and those published 4 years following their incorporation into the cosmetic world.

The data source for this study was the archive of Vogue UK magazine held by the London College of Fashion, part of the University of the Arts London. Purposive sampling methods were used to select the advertisements for study. A total of 170 advertisements were identified and selected for the study. The advertisements selected were only those for female facial cosmetics. Those for makeup, including foundation, perfume or hair products were discarded. Similarly, products aimed at the male market were excluded.

Advertisements were taken from selected years: a selection from two separate years before the introduction of non-surgical cosmetic treatments (1992 and 1993) and a selection from two separate years following the introduction of these treatments (2006 and 2007). The years 2006 and 2007 were chosen for study as they were far enough removed from 2002 to allow any possible changes in language to become apparent and are just prior to the demographic transition of 2010.

A process of emergent thematic analysis was undertaken on those advertisements selected. Thematic analysis is a form of content analysis, but one which is more concerned with patterns rather than frequency. 
In contrast to classic content analysis, this form of thematic analysis, as used by Dodds et al. (2008), uses empirically emergent, rather than theoretically generated themes. This was not about quantity, as it is a small-scale qualitative study, but about the richness of the data gathered. The methods used were based on those of Hurd Clarke (2011) and those described in her book Facing Age.

Thus, the adverts were read by both investigators and in an iterative process a number of recurring themes became evident. The advertisements were allocated to particular themes depending on the dominant message that they were articulating, although in some cases a single advertisement clearly fitted within several thematic categories. Advertisements that were replicated over several issues were included in the analysis because, as noted by Hurd Clarke (2011), repetition is a frequently used tool in advertising campaigns (see below sample and sample size).

The themes that emerged were as follows:

- Nourishing

- Moisture/hydration

- Recover/repair/re ....

- Science/pseudoscience

- Time

- War/conflict (against the signs of ageing)

- Protect

- Technology

- UV/pollution

- Eco/bio/natural

Examples of Method Used for Allocation of Adverts to Themes

Shiseido - Bio-Performance from 1992

Image: photograph of pot with lid in place. The complete pot is shown at the top of the page, while the bottom of the page is taken up with a blown up view of just the lid.

Strapline and text:

BIO-PERFORMANCE,

SUPER REVITALISER 
International Journal of Ageing and Later Life

\section{A NEW WAY TO LOOK AT AN AGE-OLD PROBLEM}

\section{HIGH TECHNOLOGY WITH THE HUMAN TOUCH}

This advertisement has been allocated to repair/recovery/regenerate/ revitalise/re ..., to the technology and to the time categories

Chanel - Beauty Precursor skincare from 1992

Image: a woman's face with two examples of products from the range in front of her.

Strapline and text:

CHANEL

BEAUTY ACTION PLAN

NOURISH, MOISTURISE, PROTECT

This has been classified nourishing, moisture/hydrate and protect.

\section{Results and Discussion}

\section{Study Object}

Vogue is a British Fashion magazine which has been published since 1916. Published by Condé Nast Publications Ltd, the London College of Fashion holds an almost complete print archive from its beginnings in 1916 to the present day. The 2014 figures showed that Vogue UK had a total readership of almost 1.4 million, of whom $87 \%$ were women. The average age of the readership was 33 years, and $63 \%$ came from social classes ABC1 (Vogue 2014). Social Grade classification is a commonly used measure among marketing and market research practitioners. It is a classification that broadly differentiates groups of people with regard to some attitudes and behaviours, as well as discriminating between the types of goods and services consumed. The classification groups people into six categories: A, B, C1, C2, D and E (National Readership Survey 2015). The readership of Vogue can therefore be characterised as consisting of middle-class professional women who are beginning to consider the fading of youth and be susceptible to the lure of the advertisements. 


\section{Sample and Sample Size}

Some advertisements had no text, only images, notably those for Clinique Daily Eye Benefits from 1992 and Turnaround Cream from 1993. These have been removed from any analysis of the language of advertisements, though they have been included for purposes of general tallies.

A total of 170 advertisements were included in the study. The totals per year and the number of duplicate advertisements per year are shown in Table 1. Overall, a total of 93 different advertisements were scrutinised.

As noted above in methods, advertisements could be included in more than one theme according to text, thus the totals will vary. The incidence of themes across the years is given in Table 2 .

Table 1. Number of advertisements per year

\begin{tabular}{lrrrr}
\hline & 1992 & 1993 & 2006 & 2007 \\
\hline Total advertisements per year & 33 & 33 & 54 & 50 \\
Adverts with no text & 1 & 2 & 0 & 0 \\
Adverts selected for text analysis & 32 & 31 & 54 & 50 \\
Duplicates & 14 & 8 & 26 & 26 \\
Total original adverts analysed & 18 & 23 & 28 & 24 \\
\hline
\end{tabular}

Table 2. Incidence of themes by year

\begin{tabular}{lrrrrrrc}
\hline & & \multicolumn{3}{c}{ Total } & & Total & Overall \\
& 1992 & 1993 & $1992 / 3$ & 2006 & 2007 & $2006 / 7$ & Total \\
\hline Theme & & & & & & & \\
Nourishing & 4 & 6 & $\mathbf{1 0}$ & 1 & 2 & $\mathbf{3}$ & 13 \\
Moisture/hydration & 13 & 14 & $\mathbf{2 7}$ & 6 & 7 & $\mathbf{1 3}$ & 40 \\
Re .. & 7 & 13 & $\mathbf{2 0}$ & 10 & 9 & $\mathbf{1 9}$ & 39 \\
Science/pseudoscience & 2 & 5 & $\mathbf{7}$ & 6 & 3 & $\mathbf{9}$ & 16 \\
"magic ingredients" & 7 & 12 & $\mathbf{1 9}$ & 15 & 12 & $\mathbf{2 7}$ & 46 \\
Time & 13 & 6 & $\mathbf{1 9}$ & 12 & 5 & $\mathbf{1 7}$ & 36 \\
War/conflict & 4 & 4 & $\mathbf{8}$ & 2 & 5 & $\mathbf{7}$ & 15 \\
Protect & 6 & 8 & $\mathbf{1 4}$ & 7 & 7 & $\mathbf{1 4}$ & 28 \\
Technology & 6 & 1 & $\mathbf{7}$ & 2 & 6 & $\mathbf{8}$ & 15 \\
UV/pollution & 4 & 8 & $\mathbf{1 2}$ & 9 & 9 & $\mathbf{1 8}$ & 30 \\
Eco/bio/natural & 1 & 6 & $\mathbf{7}$ & 5 & 2 & $\mathbf{7}$ & 14 \\
\hline
\end{tabular}


International Journal of Ageing and Later Life

\section{Reliability and Credibility Issues}

Purposive sampling (also known as judgement, selective or subjective sampling) is a sampling technique in which a researcher relies on his or her own judgment when selecting data for inclusion in a study, that is, the sampling is conducted with reference to the research questions (Bryman 2016). In terms of this study, that means that the units of analysis (the advertisements) were selected in terms of criteria that allowed the research questions to be answered. Qualitative, as opposed to quantitative, data methods allow for a greater degree of depth and richness in the data collected. Although reliability can be difficult to demonstrate with qualitative data collection, a process by which both investigators viewed the advertisements and discussed and agreed the classification ensures that credibility is maintained.

\section{Data Analysis}

Each of the themes is now discussed in more detail below:

\section{Nourishing}

This theme is characterised by an emphasis on skincare that is nurturing and wholesome. It was more popular as a theme in the pre-Botox adverts than post, represented by phrases such as "extra nourishing cream" Chanel Nutri-Principe, in 1992 and Shiseido, in 1993, who suggest that their BioPerformance cream will ensure "your skin gets the precise nourishment and care it needs." Ponds Time Release Eye Gel with crème in 1993 apparently "contains a unique nourishing complex." Although mentions decrease in the later set of advertisements, it is still represented, for example, by Rodial in 2006, which "Nourishes, refines wrinkles and plumps up collagen on skin and lips," and Clinique Continuous Rescue Antioxidant Moisturizer, in 2007, which we are told is "great news for undernourished skins everywhere." Not only is the theme less in evidence in the later advertisements, it has subtly altered in meaning to refer to skin that may not be healthy, but is "under" nourished. 


\section{Moisture/hydration}

This theme concerns the recurring and, to some extent, timeless claim made by the skincare products that they will restore and maintain the moisture of the skin. There were a total of 40 mentions across the four data sets of the hydrating and moisturising properties of the products, though it was again more popular in the pre-Botox advertisements $(27$ compared with 13 mentions). Examples include Helena Rubinstein from 1992 describing Performance $\mathrm{H}_{2} \mathrm{O}$ as "like a trickle of water on the surface of the skin delivering immediate and continuous hydration." In 1993, RoC suggests their hydra + Integral will provide "programmed moisturising in harmony with your skin." The language in 2006 is similar with Décleor promising "the ultimate natural hydration boost" with their Hydra Floral AntiPollution, and in 2007 brings Sisley's Hydra-Global which is promised to "reactivate the skin's natural hydration mechanism." The theme altered little across the time period studied but did become increasingly associated with anti-ageing and rejuvenation (Elizabeth Arden's Prevage Eye in 2007 is described as "an anti-ageing" moisturising treatment).

\section{Recover/repair/re ...}

This theme encompasses a wide range of ideas all linked by the sense that something can be made new, recuperated or done again. As a prefix, "re" is usefully multi-faceted and full of implication. The emphasis on repetition and thus the need to use a product continually in order for it to be effective is an overt marketing strategy. The inference is that each time a product is used and re-used there will be a better result. Hence, loyalty to a particular face cream is emphasised. However, "re" is also an active prefix and therefore suggests the positive action that women can take to allay the signs of ageing. Across all four years looked at there are a large number of verbs starting with the prefix "re-" utilised in the advertisements. There were an equal number of mentions in the pre-Botox and post-Botox introduction years. Examples include revitalise, reactivate, regenerate and repair from 1992, restore, refresh, rejuvenate and recharge from 1993, refine, reveal, renovate and revive from 2006, while redefine, reinforce, reshape and retighten first appear in 2007. This implies both repetition and something that is new (without any specific identification about the 
International Journal of Ageing and Later Life

innovations referred to). The prevalence of the theme across the years studied remained remarkably constant but the emphasis has altered from a focus on revitalising to redefining or reshaping the face.

\section{Science/pseudoscience and use of "magic ingredients"}

The advertisements within this theme all make an overt use of science or pseudoscience and the inclusion of allegedly powerful and exotic ingredients to create the possibly illusory sense that these products are the result of much research and development in scientific laboratories. The incidence of advertisements using this theme of scientific or pseudoscientific language remained relatively constant over the period of the study with seven mentions in 1992/1993 and nine in 2006/2007. Examples using this type of advertisement include Shiseido's 1992 slogan "science of beauty and well-being" for their Bio-Performance cream and L'Oréal's "from research to beauty" in 2006 for ReNoviste or Elizabeth Arden stating that "each formula is packed with the potency of next generation science" in 2007.

What has changed over the same time period is that the popularity of including "magic ingredients" has increased from 19 examples mentioned in 1992/1993 to 27 different ingredients in 2006/2007.

Many of the advertisements use neologisms, compound words and words that have simply been made up to sound impressive and to back up the illusion regarding the power and efficacy of the ingredients. In 1992, we are offered a "protective recovery complex," "firmex," and a "ceramide time complex" by Elizabeth Arden, "a plant marine complex" by Clarins and, best of all, a "time zone moisture recharging complex" by Estée Lauder. By 1993, Estée Lauder has moved on to a "triple alpha hydroxyl fruit acid complex," while Lancôme, RoC and Nivea Visage are offering "microspheres," "thalaspheres" and a "nanosphere complex," respectively.

Medical sounding terms are also used to make a product appear more effective. By 2006, Estée Lauder has moved on to "OGGI enzyme technology," "next-generation optics" and "bio-peptides," while Sisley is offering "encapsulating filters" and Clarins is offering "acacia micro-pearls."

By 2006, the range of ingredients being highlighted in the advertisements has expanded significantly with 15 separate "magic ingredients" 
being offered. Estée Lauder's 2006 advertisement for the product Re-Nutriv states that it contains:

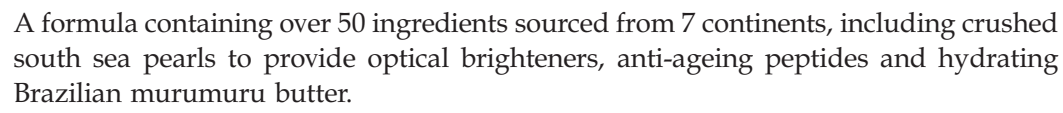

A formula containing over 50 ingredients sourced from 7 continents, including crushed south sea pearls to provide optical brighteners, anti-ageing peptides and hydrating Brazilian murumuru butter.

Here the liberal use of pseudoscientific and overtly magical ingredients from crushed south sea pearls to peptides and murumuru butter is striking.

The year 2007 brings Armani's "patented mineral complex inspired by obsidian," and "pro-tensium" and "collagen biospheres" and "ProXylane" from L'Oréal. Estée Lauder is now talking about "rare, precious ingredients" without actually specifying what these were.

According to our (limited) data set, the brands most likely to rely on "magic ingredients" were Estée Lauder, Lancôme and Elizabeth Arden (in all the years studied), although other brands also stressed their unique, and by inference, effective ingredients.

The shifting nature of the meaning associated with words is apparent in the emphasis on "complex." The word "complex" has some association with a wide range of concepts such as connectivity, composite structures, difficult or sophisticated ideas and also simultaneously cleverly evokes the biomedical world. In our data set of Vogue advertisements from 1992 to 1993, the term "complex" was evident in many of the adverts.

However, it was less in use by 2006/2007 and replaced by pseudoscientific terms such as "phyto-sunactyl 2" and "pentapeptide KTTKS." These more overtly scientific words are deliberately mystifying. They function on a representational level to signify a scientific category. The theme has remained constant in numbers across the various years but the lexicon has become increasingly inventive, drawing on a range of disciplines from earth sciences, physical and health sciences.

\section{Time}

The theme time may be characterised in several ways both in terms of carpe diem and also with relation to the speed of a product's performance. Shiseido's advert for Bio-Performance from 1992 offers "a new way to look 
International Journal of Ageing and Later Life

at an age-old problem." We are reminded of the inexorable march of time by Boots No 7 in their 1993 advert for Replenish which they promise can "help slow down the ticking of the clock." Turning back the clock is also the implication of Dior's Capture Totale from 2007 who suggest that their product is "the latest breakthrough against time."

As mentioned, companies also use time as a means of advertising the ease of use of their products, and the speed of their effects "delivers vital moisture instantly" is the promise of Estée Lauder's Skin Perfecting Lotion in 1993, while Helena Rubinstein offers "an immediate smoothing effect" in 1992. Clarins, also in 1992, suggests that their Revitalising Moisture cream can help "promote a revitalized and silky smooth skin in minutes." The popularity of the theme remained relatively constant between 1992/1993 and 2006/2007; however in the later data set, there is an increased emphasis on speed and on the future, for instance, "immediate, intensive, beauty benefits" (Clarins 2006) and l'Oréal's "express eye intervention" from 2007, rather than the past.

It is perhaps surprising that there is only limited use of the vocabulary associated with conflict and war, a topic discussed by Hurd Clarke (2011) in her study of Beauty and Ageing in Print Advertisements which also looked at Vogue among other publications. Hurd Clarke commented on the language of aggression frequently used in adverts reinforcing the notion that we are engaged in a war against the signs of ageing. There is some evidence of language that evokes this war, but this is mainly found in advertisement straplines such as Helena Rubinstein's "a decisive step in the battle against wrinkles" or Lancôme's "a double offensive against the signs of time passing" from 1992, Elizabeth Arden's 1993 advert for Ceramide Time Complex Moisture Cream which promises to "combat the visible signs of ageing" or La Prairie from 2006 who exhort you to "fight ageing where it starts" with their anti-ageing complex. In 2007, Clarins uses the slogan "science and nature join forces to combat ageing." Overall however, the emphasis in the advertisements examined here is on promises to smooth, hydrate and protect the skin rather than engage in battles against ageing.

\section{Protection}

This theme comprises those advertisements that are concerned with creating a sense of security. The implication is that by using a certain 
product, a woman can safeguard her skin and, by implication, defend herself against ageing. Nivea Visage offers "protect and survive" in 1992. At the same time, Chanel has "nourish, moisturize and protect" as the strapline for its Nutri-Principe range in 1992. In 1993, we are reminded by Shiseido that "the area around your eyes needs care and protection." Shiseido's BioPerformance cream from 1993 "provides balanced protection." In 2006, Clinique's Superdefense Triple Action Moisturiser is described as "the indispensable skincare shield," while in 2007 Clarins Extra Firming Day Cream now both "lifts and protects."

The theme has remained constant across the time span studied with a varying emphasis on the nature of the protection being offered, whereas in 1992/1993 this is much more nebulous with promises to "nourish moisturize and protect" (Chanel, 1992) and offering "balanced protection" (Shiseido, 1993). In contrast in the later time period, the protection is much more specifically focused on the dangers of ultra violet (UV) rays (see below) and urban pollution.

\section{Technology}

This is similar to the scientific theme, in that the advertisers appear to be promoting the "high tech" credentials of the product and by inference their superior performance (e.g. "advanced anti-ageing technology" from Elizabeth Arden in 1992). This approach shows a decline in 1993, but recovers its popularity in the later years studied with "high technology with the human touch" from Shiseido in 2007 and "micro-biotechnology," again from Shiseido and "a totally new technology for the eye area" offered by Estée Lauder in 2007.

\section{UV/Pollution}

This theme echoes the earlier theme of protection but whereas the latter evokes a general sense of security and safeguarding; this represents those advertisements that specifically mentioned environmental hazards. The dangers of excessive sun exposure were becoming increasingly clear in 1992, but it is interesting to note how the adverts have extended the range of hazards against which women are being offered protection. For example, in 1992, Helena Rubinstein's Skin Life TPA “Protects the skin from the harmful 
International Journal of Ageing and Later Life

elements of the environment," while Clarins' Screen Mist "Protects against electromagnetic waves and urban pollution." In 1993, Shiseido was telling us that Bio-Performance "provides balanced protection against atmospheric impurities." In 2006, Sisley is reminding us that "all day, all year the face is exposed to multiple aggressions" in order to promote their Essential Day Care. By 2007, many more companies were offering both UV and anti-pollution protection. Clarins, in 2007, was offering "an invisible shield which protects your face from UVA and UVB rays and pollution," and who were also promising "protection against free radicals," in one of the first adverts to offer protection against this particular hazard, while Lancôme was offering to "fight oxidation, fight signs of ageing." In 2006/ 2007, the incidence of this theme has increased by 50\% (18 occurrences compared with 12 in 1992/1993). Clearly, the environment is presenting a growing number of hazards that skincare manufacturers are hoping to combat. There is a notable introduction of free radicals as a threat to the skin and the ever-increasing range of SPF values in skincare.

\section{Eco/Bio/Natural}

The emphasis on "natural" has a certain enduring popularity which is still being utilised in skincare advertisements. Mentions were equal in the two data sets with seven appearances of the theme in each. "The most safe, pure and effective ingredients" are offered by RoC in 1993, while Armani claims to be "created by nature" in 2007. In 1992, Neutrogena was exhorting you to "discover your natural best," while Guerlain, in 1993, was offering Odalys with the strapline "skin is bathed in natural ingredients of plant, biological, marine and mineral origin." This emphasis on natural ingredients is then transferred to the user in 2006 when Décleor suggests that use of their Hydra Floral Anti-Pollution will result in "your skin looking and feeling naturally beautiful." Throughout their adverts, Clarins has always emphasised "the potent power of plants," while Sisley (2007) is "harnessing the best of nature's regenerating and stimulating active ingredients." Overall, the popularity of this theme has remained stable over the study period.

\section{Discussion}

The products scrutinised in this small-scale study were facial cosmetics advertised in Vogue UK in selected years (1992-1993 and 2006-2007). 
These data reflect a particular historical moment which precedes and follows the inception of the new non-surgical procedures. Principal among these developments was the introduction of minimally invasive cosmetic treatments such as Botox ${ }^{\mathrm{TM}}$ in 2002 and the first of the injectable fillers $\left[\right.$ Restylane $\left.^{\mathrm{TM}}\right]$ in 2005. It is these two dates which determined the years from which the adverts were selected: Did the introduction of these aesthetic treatments change the ways in which facial cosmetics were being advertised?

Our interest was in capturing the flavour of that moment reflecting the period during which the baby boomers were coming of age and yet before the definitive demographic transition of 2010. It is plausible that the economic conditions during the time frame studied influenced the number and content of skincare advertisements. The years 2006/2007 was a time of prosperity with growing numbers of older people with money to spend. Although the economic recession began in 2007, it did not significantly deepen until 2008. Thus, the increase in advertisements seen during the period of the study may be indicative of a means for affluent, older women to purchase something that symbolises an escape into an ideal world of beauty, pleasure and taking care of oneself. Individuals often buy things that they do not actually need, whether it is a product or service, at what might be considered an unreasonably high price, and they do this to pamper or reward themselves (Kapferer 2012).

The cosmetic companies seem to propose the notion that ageing can be reversible and repairable: that we do not have to let the world see the facial and bodily changes associated with the ageing process (Coupland 2009). In fact, you can be thought of as negligent or "morally lax" (Coupland 2009: p. 956) if you do allow the effects of ageing to show. Elizabeth Arden ran an advertisement in 2007 with the strapline "It just breaks my heart when I see younger women look older than I do" promoting their Prevage Anti-Aging Moisturizing Treatment. Allowing age-related changes to show on your face or body is constructed as a problem to which the different cosmetic companies offer a range of "solutions" (Coupland 2009). The dominant message is that the acquisition of the visible signs of ageing is unacceptable for women. There is an imperative which underlies all of the advertisements: one that insists women should hide and deny the ageing process. 
International Journal of Ageing and Later Life

The selected advertisements were allocated to various themes, as outlined in the findings. Of the themes that were prominent in the earlier period, "nourishing, in particular, has almost disappeared and moisture/hydration has halved in popularity." Due to our limited data set, it is difficult to be confident about why this is the case, but one possibility is that by the early $21^{\text {st }}$ century, manufacturers are less likely to make substantive claims for the action of their creams. Rather, they are positioning these as luxury goods that will function alongside other treatments (such as Botox ${ }^{\mathrm{TM}}$ ). The companies are not trying to compete by offering the same effects as the non-surgical cosmetic interventions but rather are stressing what they can do which the non-surgical cosmetic interventions can't, that is, to refine and redefine the skin and to enhance its properties of radiance and luminosity. Radiance is associated with a smooth skin surface as it will reflect more light, whereas a rougher skin surface will look dull in comparison. The requirement to be able to substantiate any claims may also have played a part as clinical testing is complicated, time-consuming and expensive.

Overall, it is noticeable that the language has changed in the advertisements (it is not the remit of this study to discern whether products have also changed in line with the vocabulary and whether the latter reflects this). This is evident from scrutinising the changes in popularity of themes. Above all, the vocabulary has become wider, drawing on a wide range of disciplines from earth sciences (Armani's "patented mineral complex inspired by obsidian" in 2007), through physical science (references to nextgeneration optics from Estée Lauder in 2006) to health sciences (OGGI enzyme technology, also from Estée Lauder). Medical sounding terms such as "energising complex" (Lancôme 1993), "nanosphere complex" (Nivea Visage 1993) or "phyto-concentrate" (Clarins 1993) make a product appear more effective and are designed to appeal to today's more educated cosmetics buyer, even though the true meaning may be lost on consumers. This has been noted in other studies. Weisberg et al. (2008) demonstrated that subjects are more likely to accept an explanation if it contains apparently scientific information, even if that information is not relevant to the explanation being given, a proposition that is also confirmed by Goldacre (2009).

Compound names involving combinations of words such as skintensing, lipid-replenishing or radiance-boosting are also very appealing 
as they suggest the manifold ways in which a single face cream may benefit an individual's skin. What might once have been simply a cream is now marketed as a "bio-performance synchro serum" from Shiseido (1992). The concept of a serum has become extremely popular in the beauty world but there is no actual definition of what constitutes a serum. It can be any type of cosmetic formulation (e.g. a solution or an emulsion), but it is a term usually interpreted by the public as implying a "stronger" or "more effective" product due to it containing a higher concentration of "active ingredients." By 2007, one is not enough and Clarins are marketing Generation 6 which is described as a Double Serum.

Hurd Clarke (2011) also comments on the use of product names which have been created to resemble non-surgical cosmetic procedures or to include overtly scientific or pseudoscientific language to enhance the apparent effectiveness of the product. This complicated representational system is perhaps most apparent in the regular references to what in our analysis we have called "magic ingredients"; sometimes apparently progressive, sometimes rare and expensive, these are included as a unique selling point for a product.

It is worth noting, that, even though examination of the imagery of the advertisements was not a focus of the study, the majority of the models were young. The implication being that use of the products will give you skin like theirs.

As noted, the population of the United Kingdom is steadily ageing. Therefore, there are greater numbers of older people who can be targeted by these advertisements, and equally, there is an increased cultural awareness that ageing is a central societal issue. Despite this increase in the UK population in the number and proportion of older people, the cultural imperative to remain young looking and to maintain one's appearance with the use of cosmetics (Gilleard \& Higgs 2013) is still strong. Thus, it might be hypothesised that cosmetic companies have redoubled their efforts to persuade consumers that ageing can be allayed with the judicious use of their products because there are now unprecedented numbers of older people.

$L^{\prime}$ Oréal has been a ubiquitous presence across the time periods that were examined; however, this is perhaps unsurprising given that it is one of the giant brands that owns many others and therefore has extensive resources 
International Journal of Ageing and Later Life

for marketing. The appearance of premium or luxury brands such as La Prairie (owned by the same group who own Nivea) along with the gradual disappearance of brands such as No. 7 and Neutrogena demonstrates a movement towards increasingly élite products. This may be indicative of the Vogue readership, and it may also be connected with the positioning of these expensive products as luxurious treats that are designed to boost self-esteem. However, due to the limitations in our data set, we cannot be confident about the reasons for this shift.

\section{Conclusions}

Today's consumers are presented with what appear to be choices about how they age with ageing being presented as if it is a negotiable process one that can be allayed with the right procedures and products and is subject to market forces. Ageing and anti-ageing are part of the commodified world.

The language of cosmetic advertising, according to our data set, has changed but in ways that are somewhat unexpected. There is a greater emphasis on scientific or pseudoscientific words and phrases to promote the apparently medical effects of the products, thus suggesting that the products may be as effective as the minimally invasive cosmetic interventions. A second change is that in a series of compound adjectives and phrases, the language of the advertisements suggests through subtle implication that creams, serums and elixirs are complementary to cosmetic procedures, offering effects that the procedures cannot give you such as luminous skin or radiance. Thirdly, with the range of élite or prestige products being considered here, some appear to be being marketed as luxury items, something you buy because owning and using it gives you pleasure and bestows prestige.

It is possible that these advertisements offer women an elusive (and illusory) sense of control over the ageing of the skin. Certainly, ageing is presented as an event that is located firmly at the surface level of the skin.

Fine Lines has demonstrated that the facial skincare market, as represented by the advertisements in Vogue magazine, is endlessly polymorphic and will continue to service and stoke the insecurities of women who are 
ageing. The study has also demonstrated the relevance of exploring skincare advertisements as these are part of a cultural system of representation.

\section{Corresponding Author}

Caroline Searing, London College of Fashion, Fashion Business School, University of the Arts London, 20 John Prince's Street, London W1G 0BJ, UK. Email: c.searing@fashion.arts.ac.uk

\section{References}

Abu-Saud, Z. (2013). The Dogma of advertising and consumerism. The Huffington Post. Available on http://www.huffingtonpost.co.uk/ ziad-elhady/the-dogma-of-advertising-_b_2540390.html (Accessed: April 27, 2016).

American Association of Facial Plastic and Reconstructive Surgery. (2014). Statistics on Trends in Facial Plastic Surgery. Available on http://www.aafprs.org/media/stats_polls/m_stats.html (Accessed: March 11, 2014).

Asken, S. (1990). Microliposuction and autologous fat transplantation for aesthetic enhancement of the aging face. The Journal of Dermatologic Surgery and Oncology 16(10): 965-972. doi: http://dx.doi.org/10.1111/ j.1524-4725.1990.tb01561.x.

Bayer, K. (2005). Cosmetic surgery and cosmetics: Redefining the appearance of age. Generations 29(3): 13-18.

Biggs, S. (1997). Choosing not to be old: Masks, bodies and identity management in later life. Aging and Society 17(5): 553-570.

British Association of Aesthetic Plastic Surgeons. (2014). Britain Sucks, Annual Audit. Available on http://baaps.org.uk/about-us/audit/1856-britainsucks (Accessed: February 27, 2014).

Brooks, A. (2004). 'Under the Knife and Proud of It': An analysis of the normalization of cosmetic surgery. Critical Sociology 30(2): 207-239. doi: http://dx.doi.org/10.1163/156916304323072080.

Bryman, A. (2016). Social Research Methods (5th ed.). Oxford: Oxford University Press. 
International Journal of Ageing and Later Life

Campos, R. (1987). The Semantics of Femininity in Cosmetic Advertising. Available on http://dspace.slu.edu.ph/handle/123456789/243 (Accessed: March 13, 2014).

Canning, D. (2011). The Causes and Consequences of the Demographic Transition. (The Program on the Global Demography of Aging). Available on http:// www.hsph.harvard.edu/pgda/working.htm (Accessed: March 27, 2014).

Commission on Older Women. (2015). Policy Review/Agenda 2015/Your Britain, Policy Review. Available on http:/ / www.yourbritain.org.uk/agenda-2015/ policy-review/commission-on-older-women (Accessed: April 18, 2015).

Coupland, J. (2009). Time, the body and the reversibility of ageing: Commodifying the decade. Ageing \& Society 29(6): 953-976. doi: http:/ / dx.doi.org/10:1017/S0144686X09008794.

Dade, P. (2007). All Made Up. London: Middlesex University Press.

Dalton, A. \& Berrett, J. (1994). The language of cosmetic advertising. Deseret Language and Linguistic Society Symposium. Available on https://journals.lib.byu.edu/spc/index.php/DLLS/article/viewFile/ 31424/29882 (Accessed: February 9, 2014).

de Beauvoir, S. (1972). La Vieillesse. Paris: Editions Gallinard.

Department of Health. (2013). Review of the Regulation of Cosmetic Intervenentions. Available on www.gov.uk/government/publications/review-ofthe-regulation-of-cosmetic-interventions (Accessed: March 7, 2014).

Dingman, S., Melilli Otte, M. E. \& Foster, C. (2012). Cosmetic surgery: Feminist perspectives. Women \& Therapy 35(3-4): 181-192. doi: http:// dx.doi.org/10.1080/02703149.2012.684536.

Dodds, R. E., Tseelon, E. \& Weitkamp, E. L. C. (2008). Making Sense of Scientific Claims in Advertising. A Study of Scientifically Aware Consumers, Public Understanding of Science. Available on http:/ / pus.sagepub.com/ content/17/2/211.full.pdf + html (Accessed: June 21, 2016).

Ellison, K. L. (2014). Age transcended: A semiotic and rhetorical analysis of the discourse of agelessness in North American anti-aging skin care advertisements. Journal of Aging Studies 29: 20-31. doi: http:// dx.doi.org/10.1016/j.jaging.2013.12.003.

Featherstone, M. \& Hepworth, M. (1991). The mask of ageing and the postmodern lifecourse. In M. Featherstone, M. Hepworth \& B. S. Turner (eds.), The Body, Social Process and Cultural Theory (pp. 371-389). London: Sage. 
Franks, B. (2014). 2014: The year of non-surgical facial aesthetics. Aesthetics Journal. Available on http://www.aestheticsjournal.com/ news/item/2014-the-year-of-non-surgical-aesthetics (Accessed: March 27, 2014).

Furman, F. K. (1997). Facing the Mirror: Older Women and Beauty Shop Culture. New York: Routledge.

Gilleard, C. \& Higgs, P. (2013). Ageing, Corporeality and Embodiment. London: Anthem Press.

Goldacre, B. (2009). Bad Science. London: Fourth Estate.

Hall, S. (2013). The Work of Representation. Available on http://uk. sagepub.com/sites/default/files/upm-binaries/66880-The_Work_of_ Representation.pdf (Accessed: July 30, 2015).

Hogan, S. \& Warren, L. (2012). Dealing with complexity in research processes and findings: How do older women negotiate and challenge images of aging? Journal of Women \& Aging 24(4): 329-350. doi: http:/ / dx.doi.org/10.1080/08952841.2012.708589.

Hurd Clarke, L. (2011). Facing Age. Plymouth: Rowman \& Littlefield.

Hurd Clarke, L. \& Griffin, M. (2007). The body natural and the body unnatural: Beauty work and aging. Journal of Aging Studies 21(3): 187-201. doi: http://dx.doi.org/10.1016/j.jaging.2006.11.001.

Johnson, F. L. (2008). Imaging in Advertising: Verbal and Visual Codes of Commerce. New York: Routledge.

Jones, G. (2010). Beauty Imagined. Oxford: Oxford University Press.

Kapferer, J.-N. (2012). Abundant rarity: The key to luxury growth. Business Horizons 55(5): 453-462. doi: http://dx.doi.org/10.1016/j.bushor.2012. 04.002.

Kilyeni, A. (2012). The promise of instant beauty in the language of print advertisements for cosmetics. Buletinul Stiintific al Universitatii Politehnica din Timisoara 11(1-2): 19-30. Available on http://www.ceeol.com/aspx/ getdocument.aspx?logid $=5 \& \mathrm{id}=90 \mathrm{ded}$ bace9ba45e2ad94a5b6fc5cc271 (Accessed: March 12, 2014).

Kuang, X. \& Guo, Z. (2010). A critical discourse analysis of the English cosmetic advertisements. Journal of Nanchang Hangkong University. Available on http://en.cnki.com.cn/Article_en/CJFDTOTALLCHK201002018.htm (Accessed: March 13, 2014). 
International Journal of Ageing and Later Life

Lewis, D. C., Medvedev, K. \& Seponski, D. M. (2011). Awakening to the desires of older women: Deconstructing ageism within fashion magazines. Journal of Aging Studies 25(2): 101-109. doi: http://dx.doi.org/ 10.1016/j.jaging.2010.08.016.

Mair, C., Wade, G. \& Tamburic, S. (2015). Older women want to look good despite media pressure to look young. International Journal of Aging and Society 5(1): 1-10.

Matthews, I. (2013). Trends in Facial Skincare. Available on http://www. specialchem4cosmetics.com/services/articles.aspx? $\mathrm{id}=10598 \& \mathrm{lr}=\mathrm{tfcos}$ 1401251\&li=30020670 (Accessed: March 7, 2014).

Mendelson, B. (2013). In Your Face: The True History of Plastic Surgery: The Hidden History of Plastic Surgery and Why Looks Matter. Richmond, Victoria: Hardie Grant Books.

Mitskavets, I. (2013) Attitudes towards Cosmetic Surgery - UK - May 2013. Available on http://academic.mintel.com/display/638098/ (Accessed: April 21, 2015).

Monalisa, V. E. \& Dahlan, F. (2013). An analysis of figurative language used in cosmetic advertisements. Abstract of Undergraduate Research, Faculty of Humanities, Bung Hatta University. Available on http:// ejurnal.bunghatta.ac.id/index.php?journal $=$ JFIB\&page $=$ article\&op $=$ view\&path $\% 5 \mathrm{~B} \% 5 \mathrm{D}=656$ (Accessed: March 12, 2014).

Montemurro, B. \& Gillen, M. M. (2013). Wrinkles and sagging flesh: Exploring transformations in women's sexual body image. Journal of Women \& Aging 25(1): 3-23. doi: http://dx.doi.org/10.1080/ 08952841.2012.720179.

National Readership Survey. (2015). Social Grade|National Readership Survey. Available on http://www.nrs.co.uk/nrs-print/lifestyle-and-classificationdata/social-grade/ (Accessed: November 9, 2016).

Office for National Statistics. (2012). Mortality in England and Wales: Average Life Span, Mortality in England and Wales: Average Life Span. Available on http://www.ons.gov.uk/ons/rel/mortality-ageing/mortality-in-england (Accessed: February 28, 2014).

Office for National Statistics. (2013a). Statistical Bulletin: Annual Mid-year Population Estimates, 2011 and 2012. Available on http:/ / www.ons.gov.uk/ 
ons/rel/pop-estimate/population-estimates-for-uk--england-and-wales-scotland-and-northern-ireland/mid-2011-and-mid-2012/stb---mid-2011--mid-2012-uk-population-estimates.html (Accessed: February 28, 2014).

Office for National Statistics. (2013b). Statistical Bulletin: Life Expectancy at Birth and at Age 65 for Local Areas in England and Wales, 2010-12. Available on http://www.ons.gov.uk/ons/rel/subnational-health4/ life-expectancy-at-birth-and-at-age-65-by-local-areas-in-england-and-wales / 2010-12/stb-life-expectancy-at-birth-2010-12.html (Accessed: February 28, 2014).

Prochásková, M. (2008). Cosmetics advertisments in the women's magazines: Syntactic level. Available on http://dspace.upce.cz/handle/ 10195/29688 (Accessed: March 13, 2014).

Reschke, N. (1998). Semiotic Analysis of an Ad and Readers' Interpretations. Available on http://www.aber.ac.uk/media/Students/nnr9501.html (Accessed: March 12, 2014).

Ribeiro, A. (2011). Facing Beauty: Painted Women and Cosmetic Art. New Haven, CT: Yale University Press.

Helfrich, Y. R., Sachs, D. L. \& Voorhees, J. J. (2008). Overview of skin aging and photoaging. Dermatology Nursing 20(3): 177-183.

Schroeder, J. E. (2002). Visual Consumption. London: Routledge.

Schwaiger, L. (2006). “To be forever young?": Towards reframing corporeal subjectivity in maturity. International Journal of Ageing and Later Life 1(1): $11-41$.

Segal, L. (2014). Out of Time: The Pleasures and Perils of Ageing. London: Verso.

Smirnova, M. H. (2012). A will to youth: The woman's anti-aging elixir. Social Science \& Medicine 75(7): 1236-1243.

Sontag, S. (1978). The double standard of ageing. In V. Carver \& P. Liddiard (eds.), An Ageing Population (pp. 72-80). Sevenoaks: Hodder and Stoughton.

Utz, R. (2011). Like mother, (not) like daughter: The social construction of menopause and ageing. Journal of Aging Studies 25: 143-154.

Vogue. (2014). Vogue Media Information. Available on http://www.digitalassets.condenast.co.uk.s3.amazonaws.com (Accessed: March 17, 2014). 
International Journal of Ageing and Later Life

Wan, D. C., Lim, A. T. \& Longaker, M. T. (2009). Craniofacial autologous fat transfer. Journal of Craniofacial Surgery 20(2): 273-274. doi: http:/ / dx.doi.org/10.1097/SCS.0b013e31819921d3.

Wang, Z. (2008). A Comparison of Visual and Verbal Content of Print Cosmetic Advertising between the US and China. Available on http:// www.dissertations.wsu.edu/thesis/fall2008/z_wang_091108.pdf (Accessed: March 12, 2014).

Weisberg, D., Keil, F., Goodstein, J. \& Jeremy, G. (2008). The seductive allure of neuroscience explanations, Journal of Cognitive Neuroscience 20(3): 470-477. doi: http://dx.doi.org/10.1162/jocn.2008.20040.

Woodspring, N. (2016). Baby Boomers: Time and Ageing Bodies. Bristol: Policy Press.

Woodspring, N. \& Parnell, S. (2015). Being Otherwise, Age Culture Humanities. Available on http://ageculturehumanities.org/WP/being-otherwise/ (Accessed: November 30, 2015). 